\title{
Experimental Testing of PV Module Performance
}

\author{
Mladen Bošnjaković* Marinko Stojkov, Boris Zlatunić
}

\begin{abstract}
This study compares the manufacturer's technical data of several PV modules with real measured outdoor technical data. The irradiance effect on several PV modules is examined by the changing a tilt angle and comparing different meteorological situations of sky clearness (clouds) on the modules mounted outdoor and exposed to Sun. Also, the influence of temperature and dust on the performance of a PV panel is under research using measurement methods described in the paper. The measured current and voltage data at the clean surface of the PV module correspond to the declared data of the PV module manufacturer, and in the case of fouling of the module surface with dust, a power drop of $7.39 \%$ was measured.
\end{abstract}

Keywords: dust effect; irradiance; PV generation; solar panel testing; temperature effect

\section{INTRODUCTION}

The photovoltaic energy is an interesting source of energy as it is renewable, inexhaustible and clean. It can be used in several applications meeting the cost constraints.

The amount of energy produced in the PV module is directly affected by the solar irradiance, which means that in cloudy weather the PV module produces less energy and does not produce electricity at night.

The performance of the PV module is most influenced by the collector tilt angle, which is defined concerning the horizontal position. The optimal tilt angle of a fixed PV module depends on local climatic conditions such as geographical location and season [1]. The total irradiated solar energy is affected by the duration of solar hours and the average monthly cloudiness [2].

The following articles have been selected and studied in the research field. The effect of irradiance and temperature on the performance of a PV panel was investigated by Zuhal ER et al. [3] and Aoun et al. [4]. Damasen Ikwaba Paul [5] analysed the electrical performance of three PV modules with cells connected in different configurations to address the nonuniform illumination effect.

Ramabadran and Badrilal [6] investigated the harmful effects of partial shading of series and parallel connected PV modules and compare their performance.

Abdullateef A. et al. [7] and Mohammed A. F. et al. [8] modelled solar radiation onto a photovoltaic system using MATLAB software. The results obtained by simulation were compared with the experimental results on the photovoltaic module. The influence of dust on panel efficiency has been investigated by Said and Walwil [9], Touati et al. [10], Kale and Singh [11 and Zaihidee [12]. Depending on the amount of deposited dust, the amount of light that penetrates the material of the photovoltaic cell is reduced, and thus the amount of electricity produced. For example, the reduction in PV module conversion efficiency was $10 \%, 16 \%$ and $20 \%$ for $12.5 \mathrm{~g} / \mathrm{m}^{2}, 25 \mathrm{~g} / \mathrm{m}^{2}$ and $37.5 \mathrm{~g} / \mathrm{m}^{2}$ dust density respective (Kumar et al., 2013) [13].
It is clear that the nature of dust particles, such as particle size distribution, and chemical composition also influence the result.

Otsuka et al. (1988) [14] reported that the shape of the dust particle has a strong effect on the adhesion force between the particle and surface, and thus to the amount of dust that accumulates on the panel.

Hegazy, (2001) [15] reported that the overall transmittance reduction increases with decreasing the tilt angle. They reported a $3 \%$ difference in transmittance reduction for tilt angles of $28^{\circ}$ and $40^{\circ}$.

The experimental study shows what kind of conditions affect the efficiency of a PV panel. PV panels must guarantee cost-effectiveness for investors.

It is a fact that the light spectrum changes when sunlight passes through the atmosphere. To enable an accurate comparison of the characteristics of solar cells tested at different times and in different places, the standardized spectrum and power density (irradiation) for radiation outside the Earth's atmosphere and on the Earth's surface is defined (ISO 9845-1: 1992, IEC EN 60904-3: 1989-02). Air Mass 0 means that light has not passed through the atmosphere. This irradiance on the border of the atmosphere is $1367 \mathrm{~W} / \mathrm{m}^{2}$ and is declared as solar constant.

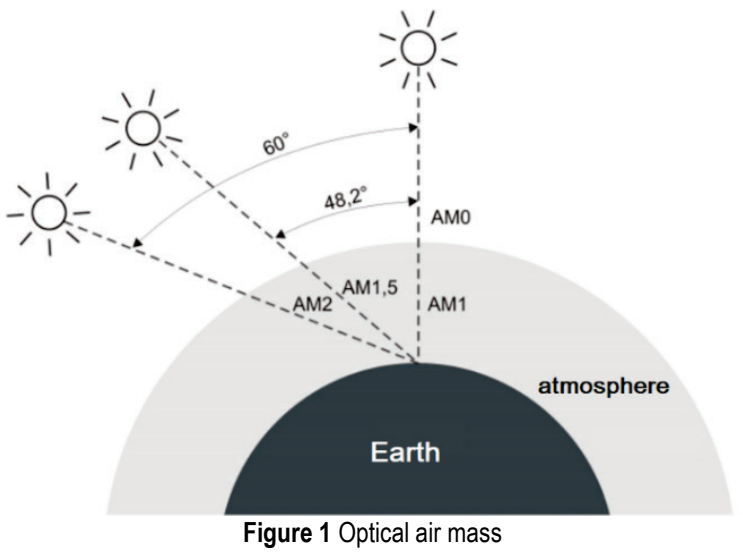

Ground-level solar radiation with the Sun at its zenith has an optical mass of air AM1, but as a standard ground-level solar 
radiation in measurements on solar radiation conversion devices, the distribution of AM1.5 (global) irradiation was adopted. It is the total irradiation (direct and diffuse) that reaches the surface of the sea if the Sun height angle is $\gamma_{\mathrm{S}}=$ $41.81^{\circ}$ (that is, the angle of incidence $\zeta_{\mathrm{S}}=48.19^{\circ}$ ). The normalized AM1.5 G spectrum is set to a value of 1000 $\mathrm{W} / \mathrm{m}^{2}$. The Sun height angle at noon position depending on the time of year and day is illustrated in Fig. 2 and 3.

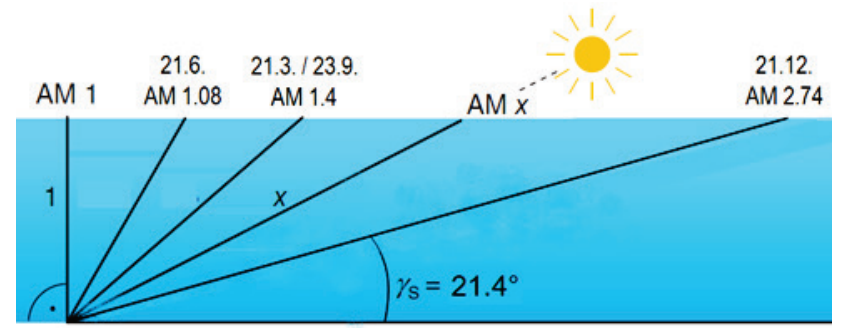

Figure 2 Air mass (at noon position) for Slavonski Brod for different days in the year

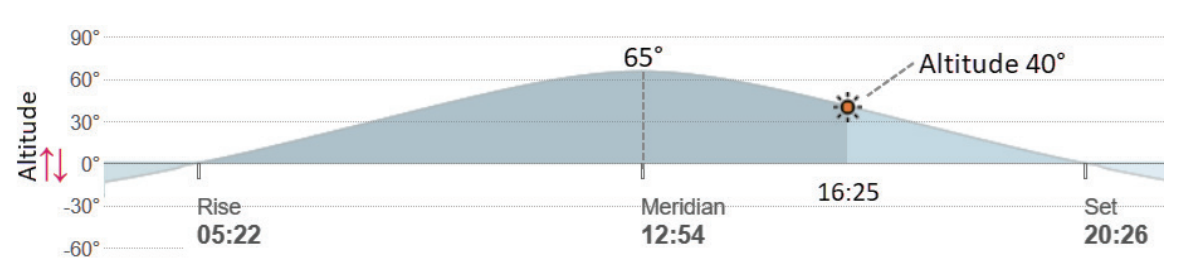

Figure 3 Sun Graph for Slavonski Brod (July 22)

\section{MATERIAL AND METHODS}

\subsection{Description of the Experimental Test}

The photovoltaic module is created by connecting photovoltaic cells, where the cells can be connected in series, which increases the voltage or in parallel in a submodule, which increases the output current. The modules produce DC, usually $12 \mathrm{~V}$ or $24 \mathrm{~V}$, but there are versions of $6 \mathrm{~V}$ and 18 V. During the operation of the PV module, degradations of properties may occur, the causes of which can be very different, for example:

- Degradation or safety issues caused by the failure of cell interconnects, solder bonds, or the bypass diodes that protect in case of shading

- Early degradation in the short-circuit current related to light-induced degradation

- Changes in transmittance associated with changes in anti-reflection coatings, encapsulation discolouration, and delamination

- Corrosion of cells and ribbons (often associated with delamination in the field)

- Junction-box failures, including non-functioning bypass diodes, etc.

In this paper, the aim is not to investigate such phenomena, but for the new module to examine the characteristics in different operating conditions and compare them with the nominal values given by the module manufacturer. Each manufacturer of PV modules takes samples from the production line and tests them following appropriate procedures to ensure the quality of their products. However, it is also interesting to do tests of PV modules that can be bought on the free market. For this purpose, appropriate PV modules were procured and the values of voltage, current, and power were measured and compared with the values stated by the manufacturer.

Equipment by which the tests were performed is (Figs. 4, 5 and 6$)$ :
- PV module SOLE $U=18 \mathrm{~V}, I=1.11 \mathrm{~A}, P=20 \mathrm{~W}$, area $1813 \mathrm{~cm}^{2}$

- PV module ANBES $U=12 \mathrm{~V}, I=0.12 \mathrm{~A}, P=1.5 \mathrm{~W}$, area $97.75 \mathrm{~cm}^{2}$

- PV module Cewaal $U=6 \mathrm{~V}, I=0.33 \mathrm{~A}, P=2 \mathrm{~W}$, area $81.5 \mathrm{~cm}^{2}$

\begin{tabular}{|c|c|c|c|}
\multicolumn{4}{c}{ Table 1 Declared parameters of photovoltaic modules } \\
\hline & $\begin{array}{c}\text { PV module } \\
\text { SOLE }\end{array}$ & $\begin{array}{c}\text { PV module } \\
\text { ANBES }\end{array}$ & $\begin{array}{c}\text { PV module } \\
\text { Cewaal }\end{array}$ \\
\hline$U(\mathrm{~V})$ & 18 & 12 & 6 \\
\hline$I(\mathrm{~A})$ & 1.11 & 0.12 & 0.33 \\
\hline$P(\mathrm{~W})$ & 20 & 1,5 & 2 \\
\hline
\end{tabular}

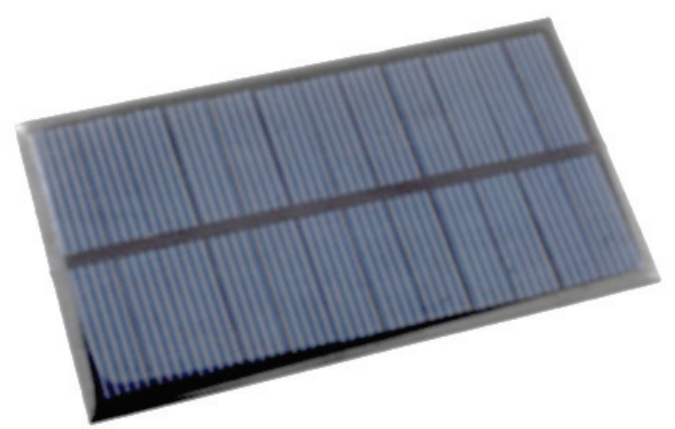

Figure 4 Cewaal PV module 6 V, 0.33 A, 2 W

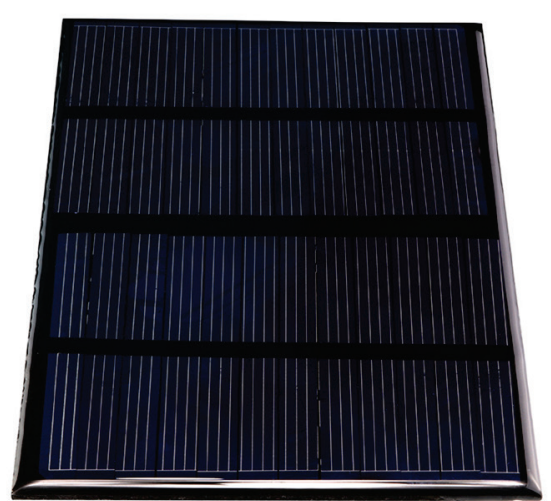

Figure 5 ANBES PV module $12 \mathrm{~V}, 0.12 \mathrm{~A}, 1.5 \mathrm{~W}$ 


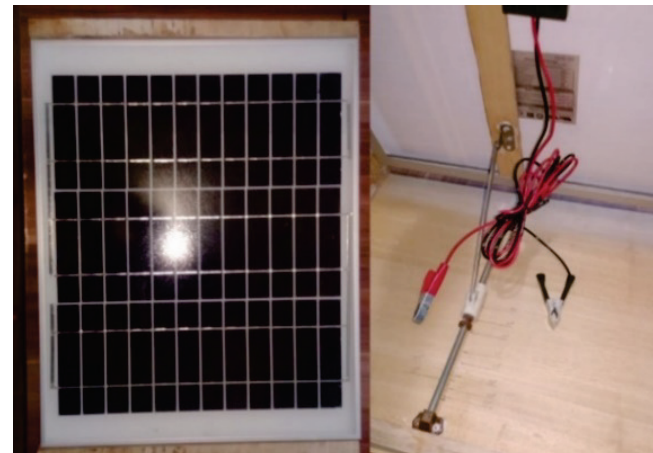

Figure 6 SOLE PV module $18 \mathrm{~V}, 1.11 \mathrm{~A}, 20 \mathrm{~W}$ with housing and slider for setting the tilt angle

Measuring equipment:

- $\quad$ Measuring Module Inpelanyu C01413 with measuring range $0-1000 \mathrm{~W}, 6.5-100 \mathrm{~V}$, current up to $19 \mathrm{~A}$ (Fig. 7)

- Lux meter brand Vktech mt30

- Infrared thermometer brand OUTEST GM320

Total (global) solar radiation on a horizontal surface from the spatial angle of $2 \pi$ steradian consists of radiation that the surface receives directly from the surface of the solar disk and scattered radiation from the sky. The instrument that measures solar radiation from the spatial angle of $2 \pi$ steradian to the receiving surface is a pyranometer. Because a pyranometer was not available for irradiation measurement, a lux meter was used to measure illuminance (Fig. 7).



Figure 7 Lux meter Vktech mt30, Thermometer OUTEST GM320 and measuring Module Inpelanyu C01413

Illuminance is a measure of photometric flux per unit area or visible flux density. Luminous efficacy in daylight is defined as the ratio of illuminance to global solar irradiation.

$K_{\mathrm{g}}=E(\mathrm{~lx}) / G\left(\mathrm{~W} / \mathrm{m}^{2}\right)$
Luminous efficacy models for the clear-sky global and direct beam are mainly related to global solar radiation and solar altitude angle and in some extent of atmospheric conditions. Littlefair [16] gives the expression for luminous efficacy:

$K_{\mathrm{g}}=91.2+0.702 \gamma_{\mathrm{S}}-0.0063 \gamma_{S}^{2}$

For measuring conditions in Slavonski Brod (season and time of day results in altitude $\left.45^{\circ}\right)$, the value $K_{\mathrm{g}}=109(\mathrm{~lm} / \mathrm{W})$ was calculated. So, the amount of irradiation on the surface can be approximately calculated using the expression:

$G\left(\mathrm{~W} / \mathrm{m}^{2}\right)=E(1 \mathrm{x}) \cdot 0.00917$

\subsection{Comparison of Measured Values of Photovoltaic Modules with Values Specified by the Manufacturer}

The circuit with components is shown in Fig. 8.



Figure 8 Scheme of the test module

The test is performed outdoors at a brightness of 86,200 lux that applying expression (1) gives $790.5 \mathrm{~W} / \mathrm{m}^{2}$. The measured ambient temperature was $32^{\circ} \mathrm{C}$.

Table 2 Measured values of photovoltaic module parameters

\begin{tabular}{|c|c|c|c|}
\hline & $\begin{array}{c}\text { PV module } \\
\text { SOLE }\end{array}$ & $\begin{array}{c}\text { PV module } \\
\text { ANBES }\end{array}$ & $\begin{array}{c}\text { PV module } \\
\text { Cewaal }\end{array}$ \\
\hline$U(\mathrm{~V})$ & 22.50 & 12.60 & 6.80 \\
\hline$I(\mathrm{~A})$ & 1.23 & 0.13 & 0.36 \\
\hline$P(\mathrm{~W})$ & 27.6 & 1.6 & 2.44 \\
\hline
\end{tabular}

The amount of deviation of radiated energy from standard conditions is about $8.3 \%$. For the SOLE module, the voltage deviation is $25 \%$, the current $10.8 \%$, and the power deviation is $38 \%$. From the above, it can be concluded that the module gives slightly better characteristics than the declared ones.

For the ANBES module, the voltage deviation is $5 \%$, the current is $0.5 \%$, and the power is $6.66 \%$. From the above, it can be concluded that the module gives approximately declared characteristics.

For the Cewaal module, the voltage deviation is $13.33 \%$, the current $9.09 \%$, and the power deviation by $22 \%$. From the above, it can be concluded that the module gives slightly better characteristics than the declared ones.

The measured values deviate from those declared by the manufacturer, and the main reason is different test conditions, i.e. a deviation of irradiated energy and higher outdoor temperature which was $32{ }^{\circ} \mathrm{C}$ during the measurement. All panels were tested by the manufacturer in standard test conditions (STC - Standard Test Condition) $1000 \mathrm{~W} / \mathrm{M} 2 ; 2 \mathrm{AM} 1.5 ; 25^{\circ} \mathrm{C}$. 


\subsection{Influence of the Tilt Angle on the Performance of the PV Module}

The test aims to define the influence of the tilt angle of the module on its efficiency. The SOLE module with the possibility of changing the tilt angle was used for this test (Fig. 9).

The test is performed by connecting the photovoltaic module to the circuit with the measuring module and the consumer and using a slider to set a tilt angle $\left(0-90^{\circ}\right)$. The test is conducted in the open air with measured illumination of 86,200 lumens. Applying expression (1), this illumination corresponds to irradiation of $783.6 \mathrm{~W} / \mathrm{m}^{2}$.



Figure 9 Measuring equipment

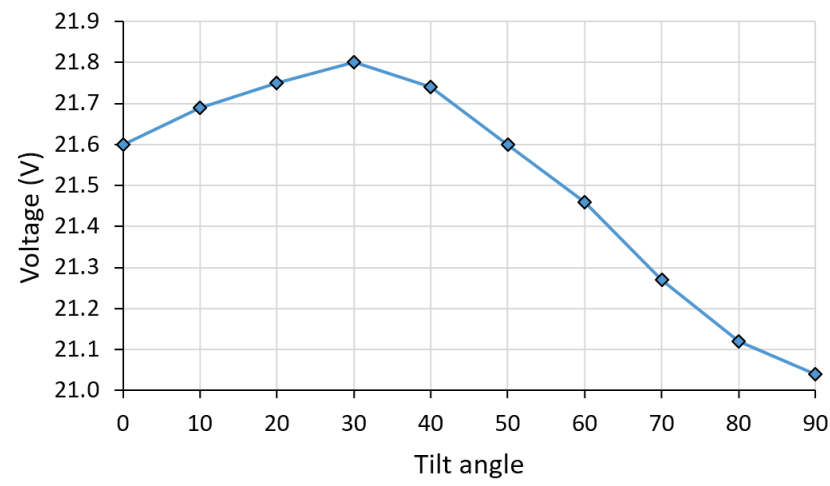

Figure 10 Voltage as a function of tilt angle

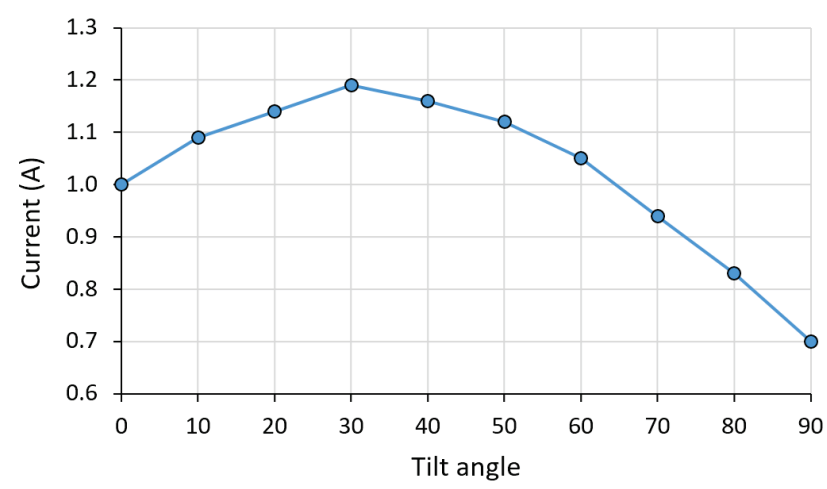

Figure 11 Current as a function of tilt angle

By changing the tilt angle of the photovoltaic module, its performance also changes. The share of direct solar radiation is dominant in the total radiation, and the maximum performance is achieved by placing the surface of the PV module perpendicular to the direction of radiation.



Figure 12 Power as a function of tilt angle

During the test, the module achieved the best performance at the tilt angle of $30^{\circ}$, which is the closest to the optimal tilt angle for the area of Brodsko-Posavska County in Republic of Croatia, which is $35^{\circ}$ (Fig. 12).

\subsection{Examination of the Influence of Clouds on the Performance of the PV module}

The tests were performed using the SOLE module. The two cases were analysed: case when the sky is cloudy and the case for a clear sky. The measured intensity of illumination for the clear sky was 84,500 lumens, and during the cloudy sky at 19,600 lumens. Calculation of irradiated energy for the case of the clear sky gives:

$G=84,500 \cdot 0.00917=775 \mathrm{~W} / \mathrm{m}^{2}$

Calculation of irradiated energy for the case of the cloudy sky gives:

$$
G\left(\mathrm{~W} / \mathrm{m}^{2}\right)=19,600 \cdot 0.00917=180 \mathrm{~W} / \mathrm{m}^{2}
$$

Table 3 Measured values for the clear sky and moderately cloudy sky

\begin{tabular}{|c|c|c|}
\hline & Clear sky & Cloudy \\
\hline$U(\mathrm{~V})$ & 21.5 & 18.7 \\
\hline$I(\mathrm{~A})$ & 1.13 & 0.21 \\
\hline$P(\mathrm{~W})$ & 24.29 & 3.92 \\
\hline
\end{tabular}

For the cloudy sky, the voltage decreased by $13.02 \%$, the current decreased by $81.41 \%$ and the power decreased by $83.74 \%$ (Tab. 3). According to the test results, it is noticeable that for the cloudy sky there is a significant drop in current and power while the voltage drops are significantly less.

\subsection{Influence of the PV Module Temperature Rise on the Voltage and Current}

The test is performed by connecting the SOLE photovoltaic module to the circuit with the measuring module and the consumer. The temperature and voltage of the PV module are then measured every 5 minutes up to 30 minutes. The procedure was performed outdoors at a light intensity of 
$84,500 \mathrm{~lx}$, which corresponds to irradiation of $775 \mathrm{~W} / \mathrm{m}^{2}$. Module temperature is also affected by the module's regime of operation, wind speed, and ambient temperature [17]. In the observed case, the ambient temperature was $28.9{ }^{\circ} \mathrm{C}$. Although the temperature of the module affects the current, at all measuring points the instrument showed a current of $1.06 \mathrm{~A}$. The reason is the limited accuracy of the instrument of $\pm 0.01 \mathrm{~A}$.

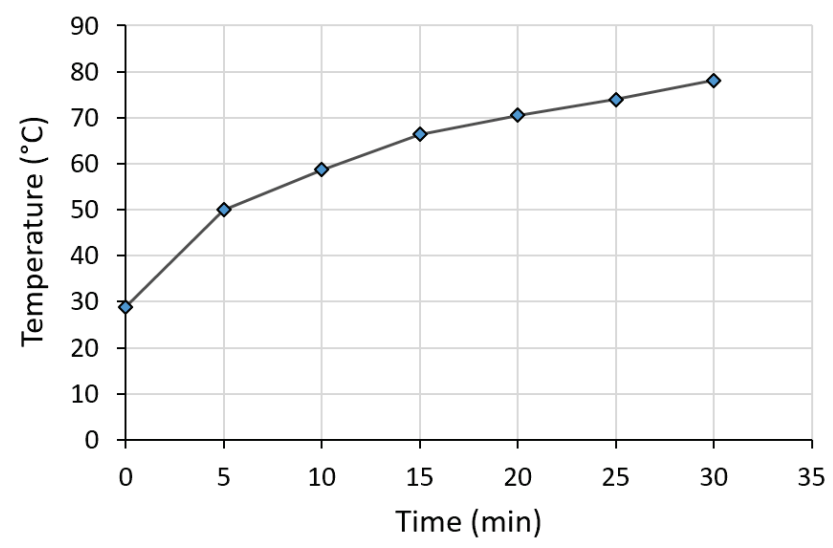

Figure 13 Temperature rise during the measurement

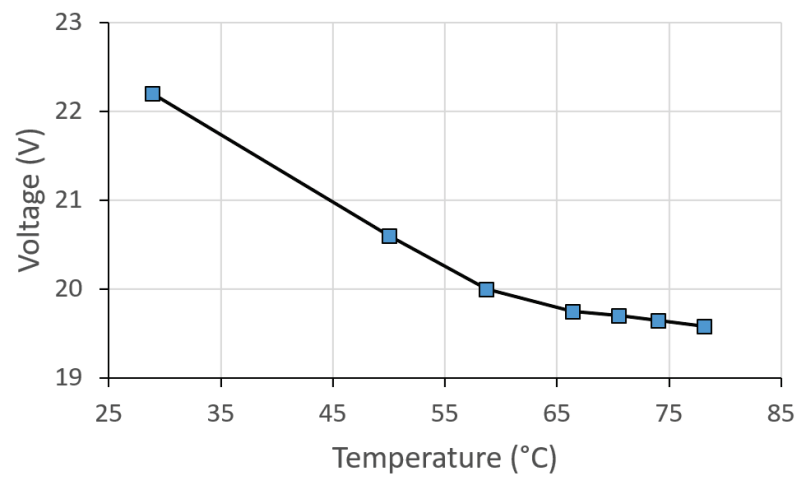

Figure 14 Influence of module temperature on the voltage

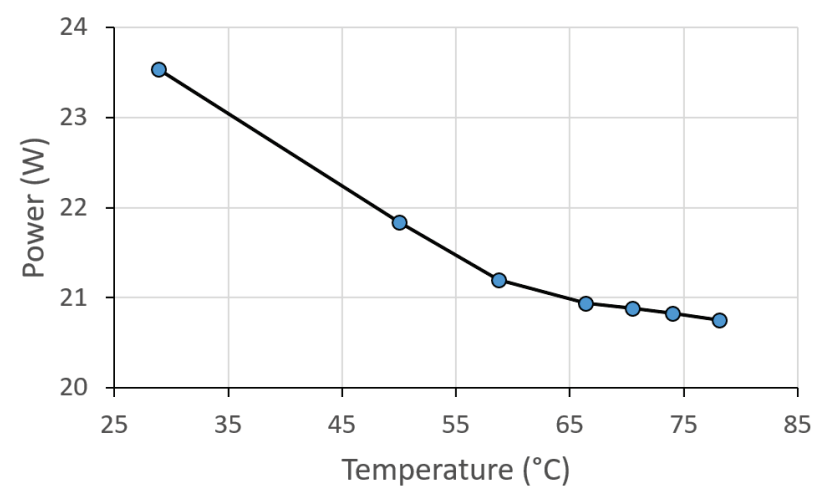

Figure 15 Influence of module temperature on the power

According to Fig. 14, it is noticeable that the voltage slowly decreases with the increasing temperature of the PV module, and the current remains unchanged. This is consistent with the findings of Tofael et al. [18] who concluded that the electrical power produced from a photovoltaic panel depends on the incident solar irradiation, and the temperature of the cells. In the analysed case, when the temperature increases from $28.9{ }^{\circ} \mathrm{C}$ to $78.2^{\circ} \mathrm{C}$, the power drops by $11.8 \%$ (Fig. 15).

\subsection{Examination of the Influence of Dust on the Performance of the PV Module}

The test procedure is performed by connecting a photovoltaic module in a circuit with a measuring module and a resistance, then measuring current, voltage, and power under the clean surface (Fig. 16) and surface covered with a layer of dust (Fig. 17). After that, the obtained value is compared. The procedure was performed outdoors, the panel was tilted at approximately $35^{\circ}$ facing south. Illumination is measured by a luminometer in the amount of 98,200 lumens. The ambient temperature was $26^{\circ} \mathrm{C}$. Calculation of the amount of irradiated energy:

$G=98,200 \cdot 0.00917=900 \mathrm{~W} / \mathrm{m}^{2}$



Figure 16 PV SOLE module with a clean surface

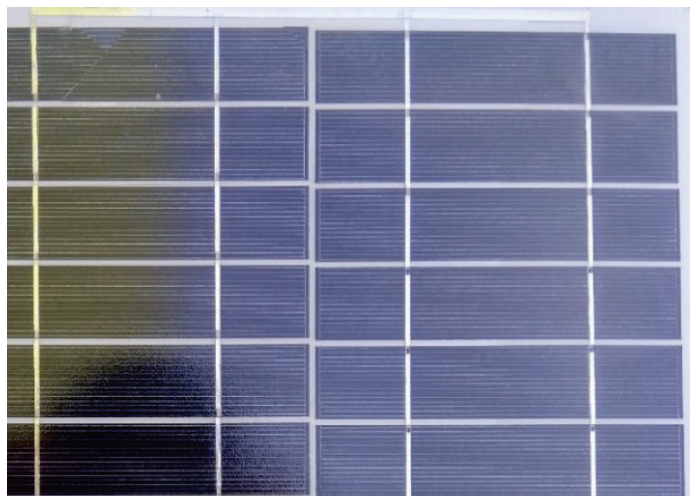

Figure 17 PV module SOLE covered with a layer of dust

Table 4 Measured voltage and current on the clean and fouled PV module

\begin{tabular}{|c|c|c|}
\hline & Clean surface & Fouled surface \\
\hline$U(\mathrm{~V})$ & 20.90 & 20.50 \\
\hline$I(\mathrm{~A})$ & 1.15 & 0.91 \\
\hline$P(\mathrm{~W})$ & 20.04 & 18.66 \\
\hline
\end{tabular}

According to the test results shown in Tab. 6, it is noticeable that in the case of PV modules with a layer of dust, all measured values are lower than for the case of clean module surface. In the case of the fouled surface, the current is lower $26.37 \%$, and the voltage drop is relatively small and 
amounts to $1.95 \%$. A voltage drop and current drop resulted in a power drop of $7.39 \%$.

From the obtained test data, it can be concluded that it is desirable to have a system for cleaning the surface of the PV module to avoid energy losses due to the influence of a layer of dust or other dirt on the surface of the PV module.

\section{CONCLUSION}

The real-life outdoor experiments support the understanding of parameters that influence the performance of a photovoltaic module in a real application. Measurement methods described and performed analyses in the paper enhance comprehension of the performance of the outdoor mounted PV modules. Influence of temperature effect and dust effect on outdoor mounted PV module surface is presented in the paper. The performed measurements show that the declared values of the PV module are achievable. Due to the increase in the module temperature, a decrease in power by $11.8 \%$ occurred, and due to the dust accumulation on the surface of the module, a decrease in the power of $6.9 \%$ was registered.

\section{REFERENCES}

[1] Kumar, A. et al. (2011). Optimization of tilt angle for photovoltaic array, International Journal of Engineering Science and Technology (IJEST), 3(4).

[2] Kimbal, H. H. (1919), Variations in Total and Luminous Solar Radiation with Geographical Position in the United States, Mon. Weather Rev., 47, pp. 769. https://doi.org/10.1175/1520-0493(1919)47<769:VITTAL>2.0.CO;2

[3] Er, Z., Rouabah, Z., Kizilkan, G., \& Orken, A. T. (2018). Standards and Testing Experiments for a Photovoltaic Module. European Journal of Science and Technology Special Issue, 12-15.

[4] Aoun, N., Bouchouicha, K., \& Chenni, R. (2017). Performance Evaluation of a Monocrystalline Photovoltaic Module under Different Weather and Sky Conditions. International Journal of Renewable Energy Research, 7(1), 292-297.

[5] Damasen Ikwaba, P. (2019). Experimental Characterisation of Photovoltaic Modules with Cells Connected in Different Configurations to Address Nonuniform Illumination Effect. Journal of Renewable Energy, Vol. 2019, Article ID 5168259, 15 pages. https://doi.org/10.1155/2019/5168259

[6] Ramaprabha, R. \& Mathur, B. (2009). Effect of Shading on Series and Parallel Connected Solar PV Modules. Modern Applied Science, 3(10), 32-41. https://doi.org/10.5539/mas.v3n10p32

[7] Jadallah, A. A., Mahmood, D. Y., \& Abdulqader, Z. A. (2014). Simulation and Experimental Testing of a PV Panel at Different Operating Conditions. IJISET - International Journal of Innovative Science, Engineering \& Technology, 1(10), 141146.

[8] Fares, M. A., Atik, L., Bachir, G., \& Aillerie, M. (2017). Photovoltaic panels characterization and experimental testing. Energy Procedia, 119, 945-952. https://doi.org/10.1016/j.egypro.2017.07.127

[9] Said, S. A. M. \& Walwil, H. M. (2014). Fundamental studies on dust fouling effects on PV module performance, Solar Energy, 107, 328-337. https://doi.org/10.1016/j.solener.2014.05.048
[10] Touati, F., Massoud, A., et al. (2013). Effects of environmental and climatic conditions on PV efficiency in Qatar. In: International Conference on Renewable Energies and Power Quality (ICREPQ'13), 20-22 March 2013, Bilbao, Spain, 275281. https://doi.org/10.24084/repqj11.275

[11] Kale, P. G. \& Singh, K. K. (2019). Modeling Effect of Dust Particles on Performance Parameters of the Solar PV Module, ICEES 2019 Fifth International Conference on Electrical Energy Systems, SSN College of Engineering, Chennai, India. https://doi.org/10.1109/ICEES.2019.8719298

[12] Zaihidee, F. M., Mekhilef, S., Seyedmahmoudian, M., \& Horan, B. (2016). Dust as an unalterable deteriorative factor affecting PV panel's efficiency: Why and how. Renew. Sustain. Energy Rev., 65, 1267-1278. https://doi.org/10.1016/j.rser.2016.06.068

[13] Kumar, E. S., Sarkar, B., et al. (2013). Soiling and dust impact on the efficiency and the maximum power point in the photovoltaic modules. Int. J. Eng., 2(2).

[14] Otsuka et al. (1988). Measurement of the adhesive force between particles of powdered materials and a glass substrate by means of the impact separation method III: effect of particle shape and surface asperity. Chem. Pharm. Bull., 36(2), 741749. https://doi.org/10.1248/cpb.36.741

[15] Hegazy, A. A. (2001). Effect of dust accumulation on solar transmittance through glass covers of plate-type collectors. Renew. Energy, 22(4), 525-540. https://doi.org/10.1016/S0960-1481(00)00093-8

[16] Littlefair, P. J. (1988). Measurements of the luminous efficacy of daylight. Lighting Research \& Technology, 20(4), 177-188. https://doi.org/10.1177/096032718802000405

[17] Kurnik, J., Jankovec, M., Brecl, K., \& Topic, M. (2011). Outdoor testing of PV module temperature and performance under different mounting and operational conditions. Solar Energy Materials and Solar Cells, 95(1), 373-376. https://doi.org/10.1016/j.solmat.2010.04.022

[18] Tofael, A., Gonçalves, T., \& Tlemcani, M. (2016). Single Diode Model Parameters Analysis of Photovoltaic cell. $5^{\text {th }}$ International Conference on Renewable Energy Research and Applications, 396-400. https://doi.org/10.1109/ICRERA.2016.7884368

\section{Authors' contacts:}

Mladen Bošnjaković, PhD, Assist. Prof.

(Corresponding author)

Technical Department, University of Slavonski Brod,

Trg Stjepana Miletića 12,

35000 Slavonski Brod, Croatia

mladen.bosnjakovic@vusb.hr

https://orcid.org/0000-0001-9882-585X

Marinko Stojkov, PhD, Full Prof.

Mechanical Engineering Faculty, University of Slavonski Brod,

Trg Ivane Brlić Mažuranić 2 ,

35000 Slavonski Brod, Croatia

mstojkov@sfsb.hr

Boris Zlatunić, BSc, student University of Slavonski Brod, Trg Stjepana Miletića 12, 35000 Slavonski Brod, Croatia bzlatunic@vusb.hr 